\title{
RÁDI NORBERT
}

\section{Az illegális migrációval kapcsolatos büncselekmények nyomozásának tapasztalatai}

\begin{abstract}
A tanulmányban az illegális migrációhoz kapcsolódó - a Csongrád Megyei Rendőr-fökapitányság által lefolytatott - büncselekmények elemzésén alapuló, egyes büncselekménytípusokra jellemző elkövetési módszereket, a nyomozások tapasztalatait kívánom bemutatni.

A magyar-szerb államhatár teljes hossza 174,4 km, ebböl Bács-Kiskun megye közel 113,2, míg Csongrád megye 61,4 km-es közös határszakaszon szomszédos Szerbiával, míg Romániával 68,2 km hosszan, így a Csongrád Megyei Rendőr-főkapitányság összesen 129,6 km schengeni külső határon látja el az államhatár örizetével kapcsolatos feladatokat. A megye határszakaszához jellemzően az úgynevezett klasszikus balkáni úton keresztül érkeznek a migránsok. Az illegális migráció és a szorosan hozzá kapcsolódó embercsempészés visszaszorítása megyénk hazai, illetve hazánk nemzetközi megítélését is befolyásolja, ezért az itt tevékenykedő rendőri szervekre kiemelt feladat hárul.

A Csongrád Megyei Rendőr-főkapitányság a határszakaszán a Szegedi, a Nagylaki és a Kiszombori Határrendészeti Kirendeltség útján, a megyei határrendészeti szolgálat közvetlen irányítása mellett látja el határrendészeti feladatait. E tevékenység eredményes teljesítéséhez a fökapitányság bünügyi igazgatósága szervezetében létrehozott migrációs ügyek és a felderítő osztálya nyújtja a nyílt és operatív bünügyi támogatást.
\end{abstract}

\section{Az embercsempész tevékenység jellemzői Magyarország schengeni övezethez csatlakozásától napjainkig}

Tekintettel arra, hogy az illegális migrációhoz kapcsolódó bűncselekmények közül a leggyakrabban előforduló deliktum az embercsempészés, így a következőkben az e büncselekményi kategóriában történő változásokat, a büntetőeljárások lefolytatása során szerzett tapasztalatokat kívánom részletesebben bemutatni. A Csongrád megye területén elkövetett embercsempészés 
dinamikája az ország schengeni övezethez csatlakozása utáni években jelentősen megnőtt, a 2009. évi 44 büncselekményről 2015-re 172 esetre emelkedett. ${ }^{1}$ Ennek hátterében a határátkelőhelyeken bevezetett szigorúbb, a schengeni egyezményben vállalt kötelezettségek betartásával végrehajtott átléptetések, illetve az EU-ba irányuló, 2014-től jelentkező koszovói, szerb migrációs tendenciák, majd az „arab tavasz” következményeként az ázsiai országok ,toló” hatása érhető tetten.

A migránsok Magyarország területére történő bejutása megvalósulhat embercsempészek segítsége nélkül, önállóan, határátkelőhelyeken embercsempészek segítségével, hamis okiratokkal elkövetett illegális határátlépésként, vagy gépjármüben megbújva elkövetett illegális határátlépés formájában, illetve a határátkelöhelyek közötti szakaszon az úgynevezett „zöldhatáron” embercsempészek segítségével.

\section{Román viszonylat}

A magyar-román határszakaszon súlyponti szerepet kaptak a kamionban elbujtatás és a hamis okmányokkal csempészés módszerei. A határon történő átjutások többségére jellemző volt, hogy a migránsok görög, török, szlovák, cseh, német honosságú szállító jármüveken (kamion, mikrobusz, teherautó) megbújva lépték át a határt illegálisan. Ezzel a módszerrel fơként román és török elkövetők szándékoztak külföldi állampolgárokat csempészni az Európai Unió területére. Romániába az illegális bevándorlók Törökországból kiindulva Bulgárián keresztül érkeztek, vagy a volt szovjet tagállamokból jutottak el. Romániában az embercsempészek logisztikai központja - a magyar határhoz közeli - Temesvár volt, ide szállították és itt pihentették az illegális bevándorlókat. Elsősorban a város mellett található menekülttáborból kerültek ki azok a külföldiek, akiket az embercsempészek Nyugat-Európába szállítottak.

Jellemző elkövetési mód volt az is, hogy a külföldieket elszállították a nagylaki határátkelő közelében található benzinkútra, innen gyalog léptek át hazánk területére, majd - már magyar oldalon - a határátkelőtől pár kilométerre lévő benzinkúton, vagy Csanádpalota térségében találkoztak a szállítást végző személlyel, aki továbbjuttatta őket a 43-as föúton, illetve az M43 autópályán a célország felé.

A bűncselekmények szervezése román, bolgár személyek kezében összpontosult. A többségében román szervezők célja az volt, hogy a határ mellé

1 Forrás: Egységes Nyomozóhatósági és Ügyészségi Bünügyi Statisztika (ENYÜBS). 
juttassák a csempészett személyeket, majd miután azok saját erőből átjutottak, továbbszállítsák őket. E határszakasz tekintetében moldáv, török, albán, szomáliai, algír, marokkói, pakisztáni, tunéziai és bangladesi állampolgárok csempészetével találkoztunk.

\section{Szerbiai viszonylat}

A Szerbiából érkező embercsempész útvonal jellemzően Görögországból indult ki, s Macedónián, Szerbián keresztül Magyarországra, majd tovább Ausztria, Nyugat-Európa felé irányult. A közel-keleti és afrikai országokból érkezők többsége Törökországba legálisan, tömegközlekedési eszközök igénybevételével utazott, majd embercsempész segítségével jutott el Görögország területére. E térség másik útvonala Koszovóból indult, és Szerbián keresztül érte el hazánk területét. A bünözői csoportok logisztikai központja a vajdasági Szabadka volt - napjainkban is az maradt -, amely közel van Csongrád megye frekventált területeihez. Ide érkeztek meg a szervezetten vagy spontán módon közlekedő külföldiek. A saját erőből érkező migránsokat a toborzók panziókban, kávéházakban, piacokon környékezték meg és ajánlották fel nekik a szolgáltatásaikat. A külföldieket panziókban vagy a határ közeli tanyákon, olcsóbb munkásszállókon, jó idő esetén erdőben felállított sátrakban pihentették, amíg az embercsempészek előkészítették és megszervezték az utazásukat, egyes esetekben hamis, hamisított úti okmányokat is beszereztek. Egyes esetekben a pihentetések elhúzódtak, és a migránsok akár hetekig is várakoztak arra, hogy továbbszállítsák őket. A tanúvallomásokban a csempészett személyek elmondták, hogy amikor már sokan voltak a pihentetőhelyen, akkor különböző színü szalagokat kötöttek a csuklójukra attól függően, hogy ki melyik célországba szeretett volna eljutni. A szalagok használatával a sétáltatók dolgát könnyítették meg, akik a migránsokat kisebb csoportokba szervezték, egy-két gépkocsinyi embert egy vagy két embercsempész kísért át a zöldhatáron.

A „sétáltatóknak” két jellemzőjük volt:

- Az egyik (tömeges jelenség), amikor a kísérők egyszerü, képzelten, felkészületlen, a határhoz közeli falvakban, szükös anyagi körülmények között élő, elsősorban szerb nemzetiségűek közül kerültek ki. Ezeket az embereket azonos nemzetiségü, idegen személyek, esetenként barátok, rokonok szervezték be, ők pedig a gyors haszonszerzés reményében, a kilátástalan anyagi helyzetük miatt vállalták a rájuk bízott feladat elvégzését. 
- A másik változatnál a sétáltatók technikailag felszereltebbek voltak, jellemző volt az éjjellátó, a hőtakaró használata. A sétáltatást sok esetben már maszkban, csuklyában végezték, így csökkentve a lebukás kockázatát.

\section{Elkövetések eszközei}

Az illegális migránsok államhatár közelébe juttatására, az embercsempészek lelepleződésének csökkentése érdekében (az egy-két fős elkövetés esetében) alkalmazott módszer a távolsági buszok igénybevétele volt. A szállítások lebonyolításához az embercsempészek sok esetben a taxisok segítségét vették igénybe. A migránsokat már a panzióknál a taxik várták, és közvetlenül a határ közelébe, vagy újabb pihentetőhelyre fuvarozták öket. Már a magyar területen is találkozhattunk a zöldhatárról történő szállítást vállaló hazai taxisokkal, akik az elfogásuk után tagadták, hogy tudomásuk lett volna az utasaik kilétéről, szándékairól.

A mobiltelefon a kapcsolattartás, a szervezés fontos eszköze volt. Jellemző, hogy a szervezet tagjainak több mobilkészüléke, úgynevezett „munkatelefonja" volt, ezeket kizárólag a büncselekmények elkövetésekor használták. A gyanúsítotti vallomásokból megállapítható volt, hogy egyes esetekben az új tagoknak mobilkészüléket adtak annak érdekében, hogy a szállítások idején elérhetők legyenek. Egyes eljárásokban a gyanúsítottak elmondták a vallomásaikban, hogy azt az utasítást kapták a megbízójuktól, hogy ha átléptek legálisan a határátkelőhelyen, kapcsolják ki a szerb telefont, a magyart pedig helyezzék üzembe. Az eljárások idején lefoglalt mobiltelefonok híváslistái és cellapozíciós adatai nemcsak a vizsgált személy kapcsolatrendszerét mutatták meg, hanem összekötötték a mobilkészülék használóját a büncselekmény elkövetési helyével is.

Az okostelefonokban található internet és a GPS nyújtott segítséget a kizárólag a büncselekmények elkövetésének idejére hazánk területére lépő, az úgynevezett „beszaladásos” módszerrel érkező, külföldön élő szállítóknak, hogy a zöldhatáron megtalálják a migránsokat, és azokat továbbjuttassák a célországba. Egyes embercsempészek a gyanúsítottként történő kihallgatásukon beszámoltak arról, hogy a beszervező koszovói embercsempész csoport tagjaitól pontos utasítást kaptak arra, hogy a szállításhoz használt gépkocsikat melyik bevásárlóközpont parkolójában találják meg, az indítókulcs hol van elrejtve, illetve a GPS-be beprogramozták azon magyarországi területeknek a pontos helyzetét, ahol fel kell venniük az „utasokat”. 
Az embercsempészésre jellemzően olcsóbb árkategóriás, öt-tíz éves, magántulajdonú vagy kölcsönzött személygépkocsikat, illetve kisméretü áruszállító gépjármüveket használtak. Korábban is megfigyelhető volt, de 2014 második felétől kifejezetten gyakorivá vált az úgynevezett „kulcsos autók” alkalmazása, ennek a lényege, hogy a magyarországi területről történő továbbszállításhoz használt gépjárműveket a szervezet bocsátotta a szállítással megbízott személy rendelkezésére. Ezekben az esetekben a kocsit forgalmas helyen (például benzinkutak, bevásárlóközpontok parkolójában) állították le, és sok esetben a nyitott gépjármüben hagyták az indítókulcsot. Az embercsempésznek ezzel a gépjármüvel kellett a kijelölt célállomásra juttatnia a migránsokat. E cselekmények tettesei föként Ausztriából, Németországból, Svájcból érkeztek, és a saját államuk által honosított személygépkocsikkal követték el a büncselekményeket. E gépkocsik felderítésére, a rendszerből kivonására operatív és nyílt intézkedéseket egyaránt tettünk, ennek következtében napjainkra a benzinkutaktól, illetve Szeged belterületéről eltűntek. A 2015. szeptember 15. előtti napokban több mint száz ilyen gépkocsit foglaltunk le, illetve a szabálytalanul elhelyezett jármüveket, amelyek a közúti forgalom biztonságát vagy a közbiztonságot veszélyeztették, a rendőrségről szóló 1994. évi XXXIV. törvény 45. § (1) bekezdése alapján elszállíttattuk a közterületekről.

\section{A szervezetek felépítése}

A vizsgált eljárásokban a szervezetek alapvető jellemzője volt, hogy nem állandó tagokkal dolgoztak. Jellemző továbbá, hogy a csempészendő migráns az országa szerinti csempészekkel (afgán, pakisztáni) egyezett meg. A bünszervezetek egész Európára kiterjedően létesítettek bázishelyeket és logisztikai pontokat, amelyeket az informatikai és a mobil távközlés révén távolról irányítottak, ellenőriztek. Számolhattak a lelepleződés kis kockázatával, és a minimális ráfordítás mellett, rövid idő alatt aránylag könnyen elérhető magas profittal. A vezető személyéhez kapcsolódó néhány bizalmi ember közvetlen kapcsolatot tartott a kiindulási, a tranzit- és célországban lévő embereivel. A kapcsolattartók rendszeres összeköttetésben voltak a kiindulási országban tartózkodó szervezőkkel. Az összekötők határozták meg, hogy az adott embercsempész mikor és melyik csoporttal induljon útnak, ők szervezték a pihentetés, szállítás, sétáltatás, továbbszállítás végrehajtását is. A gyanúsítotti kihallgatásokon az embercsempészek érdemi információkkal nem szolgáltak 
a vezetők személyére vonatkozóan, így a beazonosításuk lehetetlen volt, mivel a szervezetek egy-egy szintjén állók nem ismerik a többieket, nincsenek közvetlen kapcsolatban egymással.

A szállítást végző személy közvetlenül a célországig, vagy az útvonalon megjelenő tranzitország (Ausztria, Szlovákia) ismert találkozóhelyéig szállította a migránsokat. A szállításokat végzők körében egyre gyakoribbá vált az utazó bünözés, vagyis csak a jogsértés elkövetésének idejére érkeztek hazánkba. Ebbe az elkövetöi körbe föként Németországban, Szlovákiában, Ausztriában, Olaszországban élő, tartózkodási engedéllyel vagy állampolgársággal bíró személyek tartoztak, akik az ezekben az országokban bejegyzett személygépkocsikkal követték el az embercsempészést Magyarország területéröl. A magyar állampolgárok általában szerb megbízás és együttmüködés alapján, a határon átcsempészett személyek szállítását végezték. A szállítottak állampolgárságát vizsgálva megállapítható, hogy legnagyobb számban koszovói, albán, valamint pakisztáni és afgán állampolgárok voltak, de elöfordultak horvát, líbiai, szír, eritreai, kínai, kurd, orosz, vietnami, algír, moldáv, török, szomáliai, iraki, bangladesi, marokkói, szenegáli, szudáni és tunéziai állampolgárok is.

Jellemző volt, hogy a csempészett emberek sanyargatása is megvalósult, amikor személygépkocsi csomagtartójában szállították az embereket, vagy olyan nagy létszámú csoportot helyeztek el a jármüben, ami veszélyeztette az oxigénellátást. A lefolytatott büntetőeljárásokban minden esetben vizsgáltuk e minősítő körülmény megállapíthatóságát. Előfordult olyan nyomozás, amelyben a beszerzett szakértöi vélemény alapján az elkövetett cselekmény túlmutatott a csempészett személyek sanyargatásán, így a nyomozás vádemelési javaslattal való befejezésére különös kegyetlenséggel, több ember sérelmére és tizennégy évesnél fiatalabb személy sérelmére elkövetett emberölés büntettének kísérlete miatt került sor.

A vizsgált eljárásokat tekintve megállapítható, hogy a zöldhatáron gyalog történő embercsempészés mellett 2011 második felétől egyre nagyobb számban jelentek meg azok a migránsok, akik kamionba elrejtve próbáltak bejutni az ország területére. A gépjármüben megbújva elkövetett illegális határátlépést és jogszerütlen tartózkodást, továbbutazást azoknak a külföldieknek a körében alkalmazták, akiknek nem volt a konspiráltabb módszerek megfizetéséhez szükséges anyagi fedezetük. A próbálkozó migránsok kisebb része Görögországban került a vontatmányba, s aztán szabályosan vámzárolt jármüben észlelték őket a magyar-szerb határátkelöhelyeken. Ezt az elkövetést segítette, hogy a berakodás helyszínén (például dinnyeföldeken) illegális, ál- 
talában afgán, pakisztáni munkások dolgoztak, a rakodásnál nem volt jelen vámtisztviselő, a görög vámos nem ellenőrizte a szállítmányt, a görög-macedón vámosok egyáltalán nem vagy csak felületesen vizsgálták a rakományt, és ezt követően hitelesítették. A kamionokban megbújás módszerével elkövetett jogsértések nagyobb része Szabadkán, illetve a szerb menekülttáborok térségében, vagy a határ közvetlen közelében szerveződött. Ez esetben az embercsempészek a határtól nem túl távoli pihenőhelyeken - kihasználva a kamionosok kötelező pihenőjét - a kamionparkolókban várakozó gépjármüvek vámzárját vagy az azt rögzítő zsinórt elvágták, majd a ponyvát megbontva juttatták a migránsokat a jármübe.

A nyomozások folyamán beszerzett adatokból megállapítható volt, hogy a soförök - az eljárások döntő többségében - nem tudtak a külföldiek jelenlétéről a rakományban. Ezt bizonyította, hogy tanúvallomásaikban az illegális migránsok beszámoltak arról, hogy az embercsempészek felkészítették őket a hosszú utazások kellemetlenségeire, mire kell vigyázniuk, mikor kell felfedniük magukat. Elmondták továbbá, hogy a csempészek felhívták a figyelmüket arra is, figyeljék a mobiltelefonjukat, hogy mikor melyik ország mobiltelefon-hálózatára jelentkezik fel a készülék, így tudhatják meg, merre járnak. Ezeket az eljárásokat büncselekmény hiányában megszüntették.

Találkoztunk azonban olyan esettel is, amikor a kamionos tevékenyen részt vett az embercsempészésben szállítóként, sőt - a lebukás veszélyének elkerülése érdekében - saját maga vásárolt hungarocell szigetelőanyagot, amellyel körbepakolta, mintegy kibélelte a vontatmányt.

A szerb határforgalom-ellenőrző szervekkel, illetve a Nemzeti Adó- és Vámhivatallal közösen 2012-ben meghozott intézkedések hatására (folyamatos, visszatérő ellenőrzések a határ menti pihenőknél, röntgenes ellenőrző rendszerek telepítése, szívdobbanás-érzékelők bevetése, fokozott kutatások) 2013 közepére ez a fajta elkövetés szerb viszonylatban gyakorlatilag megszünt.

A gépjármüben megbújással elkövetett embercsempészés másik formája a gépkocsi müszerfala mögötti - egy kialakított rejtekhelyen - való megbújás volt, ezt a módszert azonban ritkábban alkalmazták, mert a csempészett emberek csekély száma (egy-két migráns) miatt nem jelentett akkora profitot, mint a csoportos embercsempészés.

A határforgalom növekedésével, valamint a migráció intenzívebbé válásával emelkedett a hamis, hamisított vagy más állampolgárok részére kiállított közokiratot felhasználó utasok száma: a 2011. évi 448 esetről 2015 végére 739-re. ${ }^{2}$ Az

2 Az Országos Rendőr-főkapitányság Rendészeti Főigazgatóság rendészeti elemző-értékelő osztály adatai alapján. 
adatok jól mutatják, hogy a migráció magával hozta a közokirat-hamisítások számának emelkedését: a migránsok a bejutásra, illetve az azt követő tartózkodás legalizálása céljából használták fel a meghamisított okiratot. A hamis, hamisított okmány beszerzésének, felhasználásának indokai jellemzően a következők voltak:

- voltak, akik saját országuk útlevél-rendészeti szabályozása miatt, vagy a személyükben rejlő indokok alapján (például büntetőeljárás alatt álltak) nem juthattak saját útlevélhez;

- felvetődött, hogy a célország, illetve az odajutáshoz szükséges tranzitország területén nemkívánatos személy;

- sokan a jobb megélhetés reményében, munkavállalási, letelepedési szándékkal próbáltak eljutni egy adott állam területére, és a szükséges feltételeknek nem feleltek meg, így legálisan nem kaphattak vízumot, beutazási engedélyt;

- elfogatóparancs hatálya alatt álló személy átlépése esetén a körözési nyilvántartásban való felfedés elkerülése érdekében változtatta meg a személyi adatait, vagy használt más nevére szóló, illetve hamis okmányt.

Megkerülhetetlen e büncselekmény illegális migrációval való összefonódása, vagy fordítva: az illegális migrációt kísérő tipikus büncselekmény a közokirat-hamisítás. A migráció növekedésével, a rengeteg igény kielégítésére és az abban rejlő jelentős haszonszerzés felismerésével, valódi hamisítómühelyek jöttek létre.

A nyomozásaink során nagyobb horderejü, a büntető törvénykönyvről szóló 2012. évi C. törvény (Btk.) szerinti bünszövetségben ${ }^{3}$ történő elkövetést évi hat-nyolc esetben, jogerős ítéletekkel igazolva sikerült bizonyítanunk.

Az embercsempészés aktivitása 2015. szeptember 15-től az év végéig terjedő időszakban erőteljesen csökkent, az év elejétől szeptember 15-ig 144, míg utána 28 esetben indítottunk büntetőeljárást. ${ }^{4}$ A markánsan új helyzetet a hármas határvédelem (jogi, fizikai és humán erős) felállítása idézte elő, ennek jogi alapját az egyes törvényeknek a tömeges bevándorlás kezelésével összefüggő módosításáról szóló 2015. évi CXL. törvény rendelkezései teremtették meg. Az illegális migráció kedvezőtlen hatásaként megnövekedett embercsempészések számának visszaszorítása céljából a törvény egyebek

\footnotetext{
3 „Btk. 459. § (1) 2. bünszövetség akkor létesül, ha két vagy több személy büncselekményeket szervezetten követ el, vagy ebben megállapodik, és legalább egy büncselekmény elkövetését megkísérlik, de nem jön létre bünszervezet;"

4 Robotzsaru Neo ügyviteli és ügyfeldolgozó rendszer adatai alapján.
} 
között módosította a Btk. embercsempészésre vonatkozó rendelkezéseit, az embercsempészés büntetési tételeinek szigorításával.

Az embercsempészés visszaszorulásához nagymértékben hozzájárult a folyamatosan szigorodó bírói gyakorlat, a jogerős ítéletek a korábbi egy-két év végrehajtásában felfüggesztett szabadságvesztésről négy-öt év letöltendő szabadságvesztés kiszabására súlyosbodtak. Ugyanakkor megállapítható, hogy az ítélkezési gyakorlatban bekövetkezö szigorítás miatt az elkövetök igyekszenek elkerülni a büntetőjogi felelősségre vonást, rendőrt észlelve sok esetben a gépkocsit hátrahagyva elszöknek, vagy a jármüvekkel önmagukat és a közlekedés más résztvevőit veszélyeztetve próbálnak menekülni.

Az embercsempész tevékenység további visszaszorításával járt a határon lefolytatott menekültügyi eljárás széles körben való alkalmazhatóságának megvalósításához szükséges törvények módosításáról szóló 2016. évi XCIV. törvény rendelkezéseinek hatálybalépése. A törvény rendelkezéseinek hatékony teljesülését nagyban elösegítette az országos rendörfökapitány által 2016. július 5-től (a törvény hatálybalépésétől) elrendelt Biztonságos határ elnevezésű határơrizeti müvelet megvalósítása. A müveletben az embercsempészek kiszürését a határőrizeti rendszer harmadik vonalában - az államhatártól számított háromezertől nyolcezer méterig terjedő sávban - a főbb közlekedési útvonalakon (5-ös, 55-ös, 43-as főutakon), autópályák (M5-ös, M43-as) felhajtóinál felállított ellenőrzési pontok, illetve a bünügyi nyomozói portyaszolgálat segíti.

Az intézkedések hatásaként az embercsempészek lehetőségei, aktivitása jelentősen csökkent, a bünszervezetek folyamatosan keresik a lehetőséget az átjuttatott migránsok továbbszállítására. A bevezetett intézkedések ellenére hazánk területére a zöldhatáron, tiltott módon bejutó illegális migránsok csempészésével azonos nemzetiségü (szíriai, afgán, pakisztáni) embercsempész csoportok foglalkoznak, amelyek az ideiglenes biztonsági határzár mentén, megfigyelésre alkalmas nagy értékü technikai eszközökkel figyelöket, drónokat alkalmaznak a határterület feltérképezésére. Napjainkban a segítségnyújtás döntően csak az ideiglenes biztonsági határzárig való kísérésben és annak megnyitásában valósul meg, átsétáltatások esetén nehezíti az embercsempész felderítését az azonos nemzetiség. A migránsok tovább juttatását jellemzően pár napos pihentetést követően, Nyugat-Európában tartózkodási engedéllyel bíró (tunéziai, marokkói, egyiptomi) szállítók végzik.

A migrációs ügyek osztályán 2016 első kilenc hónapjában ötven esetben rendeltek el nyomozást embercsempészés büntette miatt, ez az előző év hasonló időszakához képest nyolcvanszázalékos csökkenés. A nyomozások 
csak tíz százalékában történt embercsempészés a román-magyar határszakaszon. ${ }^{5}$ Itt a rendelkezésre álló bünügyi információk szerint továbbra sem folyik jelentős mértékü embercsempészés, de a lehetőségével folyamatosan számolunk.

Az embercsempészés miatt folytatott nyomozásokból a következő tapasztalatok vonhatók le:

- A sikeres fellépés alapja a nyomozó, felderítő szervek kelló érzékenysége, a titkos információgyüjtő tevékenységben rejlö - az ügyészi vagy bírói engedéllyel alkalmazható - erők, eszközök, módszerek széles körü bevetése.

- Folyamatos együttmüködés a kölcsönös információáramlás érdekében a határőrizeti feladatokat ellátó rendészeti szervekkel, a szomszédos területi szervek bünügyi szolgálatával, a Nemzeti Nyomozó Iroda kiemelt migrációs ügyek osztályával.

- A gyors adatlekérés a távközlési szolgáltatóktól, a Nemzeti Útdífizizetési Szolgáltató Zrt.-töl, a szükséges adattári lekérdezések elvégzése, ezt követő nyomozást támogató elemző-értékelő munka, amelyek minőségében befolyásolták a felderítés hatékonyságát. Az eljárásokban lefoglalt mobiltelefonok híváslistái és cellapozíciós adatai nemcsak a vizsgált személy kapcsolatrendszerét fedték fel, hanem összekötötték a büncselekmény elkövetési helyével is.

- A lefoglalt távközlési eszközök szakértő általi megvizsgálása a bizonyítást szolgáló adatok megszerzése érdekében.

- Más állam érintettsége esetén az Europol, Interpol minél gyorsabb bevonása a Nemzetközi Bűnügyi Együttmúködési Központon keresztül. A nemzetközi jellegü büncselekmények hatékony felderítése azonban csak igazságügyi együttműködés, tehát a tagállamok igazságügyi hatóságai együttmüködése mellett valósítható meg. Ennek pedig alapvetően két eszköze van, a bünügyi jogsegély, vagy az úgynevezett közös nyomozó csoportok (JIT) létrehozása. A bizonyítékok beszerzése sok esetben problematikus, mert a bizonyítékok hagyományos jogsegélyforgalom útján történő kicserélése túl lassú.

- A nyomozás terjedelmével és mélységével kapcsolatban speciális érdekösszeütközés van, hiszen az egyik cél a fair, de gyors eljárásban a bíróság elé állítás, a másik viszont magának a bủnszervezetnek a feltérképezése, ami meglehetősen időigényes folyamat. A célravezető eljárási formáról azonban mindig az adott körülmények figyelembevételével kell dönteni.

- A bünügyi felderítő munka hatékonyságát növeli, ha az információk egy kézben összpontosulnak.

5 Uo. 


\section{A határzárral kapcsolatos büntetőeljárások tapasztalatai}

Az egyes törvényeknek a tömeges bevándorlás kezelésével összefüggő módosításáról szóló 2015. évi CXL. törvénnyel a jogalkotó három új tényállást kriminalizált a Btk. közigazgatás rendje elleni büncselekményeket tartalmazó fejezetében, ezek: a határzár tiltott átlépése (Btk. 352/A §), a határzár megrongálása (Btk. 352/B §) és a határzárral kapcsolatos építési munka akadályozása Btk. 352/C §). A határzár tiltott átlépését az követi el, aki az ilyen létesítménnyel védett határszakaszon, a létesítményen keresztüljutva, azt kijátszva lép be Magyarország területére jogosulatlanul. Sui generis büncselekményként került a Btk.-ba az államhatár rendjének védelmére szolgáló létesítmény megsemmisítése vagy megrongálása. Ebben az esetben a védett jogtárgy nem elsősorban a tulajdonjog, hanem az államhatár rendjének védelme. Jelenleg az ötvenezer forintot el nem érö kárt okozó rongálás nem bủncselekmény, hanem csak szabálysértés, így az államhatár védelméről gondoskodó létesítmény rongálása a legtipikusabb esetekben nem nyújt megfelelő védelmet. A törvény ezt az elkövetési formát erre tekintettel szabályozza az okozott kár mértékétől függetlenül egytől öt évig terjedő szabadságvesztéssel fenyegetett szubszidiárius büncselekményként.

Szintén módosult a büntetőeljárásról szóló 1998. évi XIX. törvény (Be.), a jogalkotó célja az volt, hogy a megindult büntetőeljárások minél hamarabb érdemi döntéssel végződjenek. Ennek érdekében új eljárási formát vezetett be a határzárral kapcsolatos büntetőeljárásokra. A határzárral kapcsolatos büncselekményekkel összefüggő eljárásokat a büntetőeljárás általános szabályaihoz képest rövidebb idő alatt kell lefolytatniuk az igazságügyi szerveknek. A Be. új XXVI/A. fejezete azonban e rövidebb határidejű elbíráláson belül is speciális sürgősségi szabályt ír elő a tömeges bevándorlás okozta válsághelyzet idején, annak területén elkövetett, határzárral kapcsolatos büncselekményekkel összefüggésben. Rögzíti ugyanis, hogy ebben az esetben a büntetőeljárást minden más ügyet megelőzően kell lefolytatni. Az eljárások gyorsításának elősegítése érdekében jelentős változás, hogy a határzárral kapcsolatos büncselekmények esetén a terhelt a büncselekményre a törvény által elöírt büntetési tételhatártól függetlenül bíróság elé állítható. Emellett a bíróság elé állítás határidejét harmincról tizenöt napra, tettenérés esetén nyolc napra szállította le, egyben ennek megfelelően rögzíti az iratok ügyésznek történő visszaküldésére vonatkozó szabályokat.

A határzár tiltott átlépése miatt az eljárások (3067) csak rendőri elfogás esetén, tettenéréssel, vagy mélységi elfogással indulnak. A tettenéréseket spe- 
ciális technikai képrögzítő eszközök használata (hőkamera, videokamera, drónok felvételei) segíti elö. A mélységbeli elfogásnál viszont csak idegenrendészeti eljárásban történő beismerés alapján van lehetőség a büntetőeljárás megindítására, a megalapozott gyanú közlésére. A büncselekmények jellemző elkövetési módszere, hogy az ideiglenes biztonsági határzár, illetve a gyorstelepítésủ drótakadály alatt úgy jutnak át, hogy botokkal vagy más eszközökkel megemelik, vagy különféle takarókat, ruházatot terítenek rá, és átmásznak magyar területre. A határzár megrongálása büncselekményt (692) jellemzően a határzár valamilyen eszközzel történő átvágásával követik el. A nyomozásokat minden más eljárást megelőzően folytatjuk le ezekben az ügyekben. Döntő többségüket bíróság elé állítással (2909), vagy vádemelési javaslattal (52) fejezzük be. ${ }^{6}$

Az eljárások „szúk keresztmetszete” a tolmácsok alacsony száma. A tolmácsolási nehézségeinket azonban enyhíti, hogy a Csongrád Megyei Rendör-főkapitányságon található egy már a korábbi években elkészített, terjedelmes tolmácsjegyzék, így az intenzívebb időszakokban erre folyamatosan támaszkodhatunk.

Az eljárások eredményes lefolytatásához elengedhetetlen a napi szintü együttmüködés az ügyészséggel, bírósággal, a Bevándorlási és Állampolgársági Hivatallal és az idegenrendészeti eljárásokat lefolytató idegenrendészeti osztályokkal egyaránt.

Eljárásaink során általános alapelv, hogy a családokat nem lehet szétszakítani, illetve az esetleg szétválasztott családokat a későbbi idegenrendészeti eljárás, kiutasítás végrehajtásakor újra egyesíteni kell. Ennek érdekében a családokról külön nyilvántartást vezetünk, ezt naponta küldjük a társszerveknek, elősegítve a folyamatban lévő eljárásokban a családegyesítést.

\section{Összegzés}

„A közös migrációs politika kialakitása során hosszú távra kell tervezni, hiszen a migráció, mint társadalmi jelenség hosszú távon fejti ki hatásait."” Úgy gondolom, Windt Szandra megállapításai napjainkban is aktuálisak és valósak, így azokat nem érdemes vitatni.

6 Uo. A 2015. szeptember 15. és 2016. október 25. között lefolytatott eljárások.

7 Windt Szandra: Az illegális migráció kriminológiai jellemzői. PhD-értekezés. Miskolci Egyetem Állam- és Jogtudományi Kar Deák Ferenc Állam és Jogtudományi Doktori Iskola, Miskolc, 2008, 307. o. http://193.6.1.94:9080/JaDoX_Portlets/documents/document_5733_section_1133.pdf 
Megállapítható, hogy az „illegális csatornák” ellenőrzéséért felelős rendvédelmi szervekre nagy felelősség hárul az elöttünk álló évtizedekben is. Az embercsempész tevékenységben az elmúlt években bekövetkezett folyamatos és gyors változásokra a szakmai és társadalmi követelményeknek egyaránt megfelelő hatósági válasz csak a bünügyi szervek konstruktív együttműködése mellett adható. Ennek megvalósulásához szükséges, hogy a bünüldözők ne csak ügyeket, hanem tendenciákat, folyamatokat kezeljenek.

\section{IRODALOM}

Baumann, Zygmunt: Globalizáció. A társadalmi következmények. Szukits Könyvkiadó, Szeged, 2002

Csobolyó Eszter: A nem-kormányzati szervezetek feladatai a tömeges migráció kezelésében, részvételük továbbfejlesztési lehetőségei. Határrendészeti Tanulmányok, 2016/3.

Gaál Gyula: Az embercsempész tevékenység megjelenési formáinak és módszereinek változásai a Magyar Köztársaság államhatárán 1991-2003 között. Határrendészeti Tanulmányok, 2005/4., Különszám

Hautzinger Zoltán - Hegedüs Judit - Klenner Zoltán: A migráció elmélete. Nemzeti Közszolgálati Egyetem Rendészettudományi Kar, Budapest, 2014

Ritecz György - Sallai János: A migráció trendjei, okai és kezelésének lehetősége. HannsSeidel Alapítvány, Budapest, 2015

Windt Szandra: Az illegális migráció kriminológiai jellemzői. PhD-értekezés. Miskolci Egyetem Állam- és Jogtudományi Kar Deák Ferenc Állam és Jogtudományi Doktori Iskola, Miskolc, 2008

\section{JOGSZABÁLYOK}

A rendőrségről szóló 1994. évi XXXIV. törvény

A büntető törvénykönyvröl szóló 2012. évi C. törvény

A büntetőeljárásról szóló 1998. évi XIX. törvény

Az egyes törvényeknek a tömeges bevándorlás kezelésével összefüggő módosításáról szóló 2015. évi CXL. törvény

A határon lefolytatott menekültügyi eljárás széles körben való alkalmazhatóságának megvalósításához szükséges törvények módosításáról szóló 2016. évi XCIV. törvény 